Malgorzata Kowalik-Olubińska

https://doi.org/10.26881/pwe.2020.49.07

ORCID: 0000-0001-9687-9862

Uniwersytet Warmińsko-Mazurski w Olsztynie

malgorzata.olubinska@uwm.edu.pl

\title{
Od binarności do nowej fali - między modernizmem a postmodernizmem w nowej socjologii dzieciństwa
}

\section{Summary \\ From the binary to the new wave - between modernism and postmodernism in the new sociology of childhood}

The area of the author's investigations is the new study paradigm, known as the new sociology of childhood, formulated at the end of the 20th century. The subject of the author's interest is one of the currents, known as the new wave, which the author considers in the context of modernism, out of which the current of the new wave has emerged, and postmodernism, which constitutes the significant intellectual background for it. The objective of the article is to depict the way of understanding both the child and childhood contained within the investigative current of the new wave, which has enabled the child to be considered as a fully dimensional and biological, psychological and social being, as well as adaptation of the holistic understanding of childhood as a phenomenon within which culture meets nature, whereas what is social inextricably intertwines with what is natural. The author discusses the modernistic dichotomies, the criticism of which has contributed to the emergence of the new wave of study, within the context of the assumptions of the new sociology of childhood. The author presents conceptual categories which make it possible to get out of dichotomy when describing and analyzing childhood. At the end of the article the author indicates the implications of the assumptions of the new wave analyzed in the article for education of the child.

Keywords: child, childhood, new sociology of childhood, modernism, postmodernism, holistic understanding of child and childhood

Słowa kluczowe: dziecko, dzieciństwo, nowa socjologia dzieciństwa, modernizm, postmodernizm, holistyczne rozumienie dziecka i dzieciństwa

\section{Wprowadzenie}

Twórcy paradygmatu nowej socjologii dzieciństwa ${ }^{1}$, ukształtowanego na przestrzeni ostatnich dwóch dziesięcioleci XX w., dokonali istotnej zmiany w zakresie konceptualizacji kategorii dziecka i dzieciństwa (Prout, James 1990; James i in. 1998). Odwołując

1 Nadanie nowemu paradygmatowi nazwy ,nowa socjologia dzieciństwa” miało sygnalizować umiejscowienie tworzonego pola badawczego w obrębie socjologii. Z czasem jednak włączono do niego problematykę 
się do interpretatywnych i interakcyjnych nurtów w socjologii, zakwestionowali tradycję redukowania dzieci do kategorii osób pasywnych i bezbronnych, pozbawionych możliwości autentycznego uczestnictwa w życiu społecznym. Zamiast tego postawili tezę o konieczności uznania dzieci za aktorów społecznych obdarzonych zdolnościami sprawczymi. Istotną rolę w formowaniu się założeń nowej socjologii dzieciństwa odegrał konstruktywizm społeczny, który w latach 80. ubiegłego wieku zyskał na szczególnym znaczeniu w naukach społecznych. Przyjęcie tej perspektywy teoretycznej przyczyniło się do uznania dzieciństwa za konstrukt społeczny, założono bowiem, że nie sprowadza się ono do stanu „biologicznej niedojrzałości, nie jest ani naturalną, ani uniwersalną cechą ludzkich grup, lecz jawi się jako specyficzny komponent strukturalny i kulturowy wielu społeczeństw" (Prout, James 1990: 8). Konstruktywiści społeczni zwracają ponadto uwagę na konieczność ujmowania dzieciństwa w wymiarze historycznym i temporalnym, optują za dyskursywną naturą jego konstruowania. Są zatem bliscy poglądu, że dzieci „nie są kształtowane przez siły natury czy siły społeczne, ale raczej zamieszkują świat znaczeń tworzony samodzielnie w interakcjach z dorosłymi" (Jenks 2008: 127).

W okresie konsolidowania się nowej socjologii dzieciństwa (na przełomie XX i XXI w.) wyłonił się w jej obszarze nurt badawczy zwany nową falą (Ryan 2012), do którego powstania przyczyniła się podjęta przez część badaczy krytyka dychotomicznego ujmowania kategorii służących do opisu dzieci i dzieciństwa, takich jak sprawczość vs struktura, bycie vs stawanie się czy natura vs kultura. Obecność takiego podejścia do kategoryzacji dzieciństwa wiązali oni przede wszystkim z uwikłaniem nowego paradygmatu w modernistyczne myślenie o świecie, dla którego: „główną ramą pojęciową (...) jest opozycja - a ściślej mówiąc: podział dychotomiczny" (Bauman 1995: 28). Za warunek wyzwolenia się spod wpływu modernistycznej mentalności uznano przyjęcie niedualistycznych narzędzi do opisu i analizy kategorii dziecka i dzieciństwa. Oznaczało to zwrot w kierunku tych nurtów myślenia o świecie, które kwestionowały zasadność idei modernistycznych - do takich nurtów można zaliczyć postmodernizm. Według postmodernistów nie istnieje jedna interpretacja rzeczywistości, definitywność jest zastępowana przez częściowość, fragmentaryzację i epizodyczność. Do opisu świata używają zatem takich kategorii, jak pluralizm, relatywizm, sceptycyzm, emancypacja, dekonstrukcja czy przygodność. Ta ostatnia kategoria sygnalizuje, że poglądy i myśli człowieka są tworem określonego czasu i miejsca. Oznacza ona także brak konieczności istnienia czegoś, wskazuje na wartość indywidualności i różnorodności w społeczeństwie liberalnym oraz na prywatyzację norm moralnych (Rorty 2009).

Inicjatorami ruchu zmierzającego do rewizji założeń ontologicznych nowej socjologii dzieciństwa stali się badacze pozostający pod wpływem idei formułowanych przez europejskich myślicieli tej miary, co Michel Foucault, Jacques Derrida, Bruno Latour,

\footnotetext{
z innych dziedzin, takich jak: geografia, prawo, edukacja i in. W związku z tym zaczęto używać terminów „społeczne badania nad dzieciństwem” lub „badania nad dzieciństwem” (childhood studies) (por. np. James i in. 1998; Qvortrup i in. 2009; Tisdall, Punch 2012). To ostatnie określenie dominuje w najnowszej literaturze przedmiotu. W swoim artykule stosuję termin „nowa socjologia dzieciństwa”, odnoszę się w nim bowiem do przemian, których początki sięgają wczesnego okresu istnienia childhood studies.
} 
Georges Bataille, Gilles Deleuze, Félix Guattari. Wykorzystując zaplecze intelektualne ich myśli, badacze ci podjęli próbę wyjścia poza wskazaną binarność kategorii pojęciowych przez ukazanie dzieciństwa w całej jego złożoności i wielowymiarowości, z odwołaniem się do kategorii hybrydyczności i mnogości/wielorakości (Lee 2001; Prout 2005, 2011; Ryan 2012).

W kolejnych częściach artykułu, który w istocie rzeczy dotyka ontologicznej warstwy założeń nowego paradygmatu, omawiam wpisane $\mathrm{w}$ te założenia modernistyczne dychotomie, a następnie przedstawiam proponowane przez wybranych autorów kategorie pojęciowe umożliwiające wyjście poza dychotomie w opisywaniu i analizowaniu dzieciństwa.

\section{Problematyzacja modernistycznych dychotomii w nowej socjologii dzieciństwa}

Obecność dychotomicznie ujmowanych kategorii odnoszących się do dziecka i dzieciństwa w nowym paradygmacie badawczym dowodzi jego zakorzenienia w modernistycznym myśleniu o świecie. Modernizm bowiem szuka w świecie porządku, przejrzystości i jednoznaczności, obawiając się niejasności, nieuporządkowania i wieloznaczności. Obawy te - jak pisze Zygmunt Bauman - sprawiają, że modernizm jest owładnięty obsesją wyznaczania wyraźnych granic, tendencją do posługiwania się binarnościami (Bauman 1995). Tendencja ta jest widoczna w socjologii modernistycznej, o czym świadczą opozycje, którymi posługują się socjologowie przy opisywaniu świata społecznego, np. struktura vs sprawczość, lokalność vs globalność, ciągłość vs zmiana.

To właśnie ten język binarnych opozycji stał się narzędziem, które posłużyło do wykreowania przestrzeni dla dzieciństwa, wcześniej nieobecnego w dyskursie socjologicznym. Inaczej mówiąc, włączenie dzieciństwa w obręb socjologii dokonało się w dużym stopniu za pośrednictwem zestawu dychotomicznych opozycji. Dwie kluczowe kategorie pojęciowe nowej socjologii dzieciństwa: dziecięca sprawczość i dzieciństwo jako struktura społeczna, zostały wprost zaczerpnięte z socjologii modernistycznej. Doprowadziło to - jak pisze Alan Prout - do nieoczekiwanych paradoksów. Oto bowiem, gdy w okresie późnego modernizmu teoria społeczna przesunęła kategorię podmiotu poza centrum swojego zainteresowania, socjologia dzieciństwa ją wyeksponowała, koncentrując się na dziecięcej subiektywności. Gdy „socjologia sięgała po metafory mobilności, płynności i złożoności, socjologia dzieciństwa wznosiła konstrukcję dzieciństwa jako struktury" (Prout 2005: 62).

Do zestawu dychotomii wpisanych w nową socjologię dzieciństwa zalicza się takie opozycje, jak sprawczość vs struktura, dziecko vs dorosły, stawanie się vs bycie oraz natura vs kultura. Odnosząc się do opozycji sprawczość vs struktura, można dostrzec, że na jednym jej biegunie usytuowane jest dziecko, któremu przypisuje się status aktora społecznego, przyznając tym samym, że jest ono obdarzone zdolnością do wpływania na zdarzenia, na to, co dzieje się z nim samym i wokół niego (Prout, James 1990). Na drugim biegunie natomiast znajduje się dziecko, które uznaje się za zależne od dorosłych, pozbawione możliwości wpływania na otoczenie i aktywnego uczestnictwa w życiu 
społecznym. Przyjęcie takiej perspektywy postrzegania dziecka nie uwzględnia możliwości istnienia „stanów pośrednich”, dziecko jest albo aktywne i autonomiczne, albo bierne i zależne od otoczenia. Tymczasem to, czy i w jakim zakresie dziecko podejmuje działania autonomiczne, zależy od wielu czynników, zarówno wewnętrznych, związanych z osobą dziecka (np. z jego motywacją do podjęcia aktywności o tym charakterze), jak i całego zestawu czynników tkwiących w kontekście społeczno-kulturowym. Należą do nich m.in. relacje dziecka z osobami dorosłymi, których jakość może wpływać facylitująco lub ograniczająco na dziecięcą sprawczość (Mayal 2002). W podobny sposób może oddziaływać na aktywność dziecka środowisko edukacyjne, zwłaszcza rodzaj i charakter norm, jakie w nim obowiązują (Vandenbroeck, Bouverne-De Bie 2006).

Literatura przedmiotu dostarcza przykładów dziecięcej bezradności, zapotrzebowania na troskę, opiekę i wsparcie ze strony osób dorosłych, a równocześnie dziecięcej odporności psychicznej, zaradności i sprawczości. Można tu przywołać chociażby obrazy dzieci egzystujących w warunkach wyznaczanych przez skrajne ubóstwo lub, z czym mamy coraz częściej do czynienia, negatywne konsekwencje zmian klimatycznych (Kousky 2016). Dzieci dają się w nich poznać jako osoby bezradne, zdające się na opiekę innych ludzi, ale także jako osoby zdolne do samodzielnego stawiania czoła trudom codzienności, dbania zarówno o siebie, jak i o innych (rodziców, kolegów, przyjaciół, społeczność lokalną) (Mizen, Ofosu-Kusi 2010; Kowalik-Olubińska 2020).

Poruszane kwestie łączą się z dychotomią dorosły vs dziecko. Stanowi ona podstawę budowania obrazu dzieciństwa jako odrębnego stanu bycia, stanu wyraźnie oddzielonego od dorosłości. Sprzyja też postrzeganiu dzieciństwa jako okresu, w którym dziecko stopniowo staje się w pełni ukształtowanym człowiekiem dorosłym. Zdaniem Nicka Lee posługiwanie się tą opozycją miało sens w społeczeństwach modernistycznych, natomiast w obliczu głębokich przemian, jakim podlegają współczesne społeczeństwa, odnoszenie się do tej opozycji traci sens (Lee 2001). Uwagę tę można także odnieść do opozycji stawanie się vs bycie, w której przeciwstawia się wizję dziecka jako osoby-dorosłej-w-procesie-stawania się wizji dziecka jako osoby w pełni ukształtowanej. Dziecko jest zatem traktowane albo jako osoba, która biernie oczekuje na przejście do świata dojrzałych, silnych i racjonalnych osób dorosłych, albo jako osoba zdolna do oceny i rozumienia sytuacji, w jakiej się znajduje, i do podejmowania samodzielnych działań. Należy oczywiście dodać, że dziecięca kompetencja w zakresie rozumienia złożoności świata społecznego, radzenia sobie z problemami, jakie niesie codzienne życie, zależy od splotu wielu różnorodnych czynników. Badacze podkreślają, że jest ona uzależniona przede wszystkim od kontekstu społecznego, natury problemu, zasobów wiedzy osobistej i doświadczenia dzieci oraz zakresu wsparcia, jakie otrzymują od innych osób (Alderson, Goodwin 1993). Kompetencję można zatem uznać za właściwość, która charakteryzuje wszystkich ludzi, młodszych i starszych, a jej zakres zależy od indywidualnego doświadczenia, okoliczności i kontekstu społecznego działających.

W świetle przedstawionych tez nie dziwią krytyczne uwagi Nicka Lee, kierowane pod adresem nowej socjologii dzieciństwa. Autor uważa, że nadmiernie eksponuje się w niej 
ideę dziecka w pełni kompetentnego i zdolnego do samodzielnego działania. Utrwala to mit dziecka autonomicznego i niezależnego, tak jakby możliwe było stawanie się i bycie człowiekiem bez konieczności przynależenia do złożonej sieci relacji społecznych (Lee 2001). Autor sugeruje ponadto, że wszyscy ludzie, zarówno dzieci, jak i dorośli, powinni być postrzegani ,jako osoby-w-procesie-stawania-się, z których każda jest niekompletna/niedoskonała (incomplete) i niesamodzielna/zależna od innych (dependent)" (Lee, za: Prout 2005: 67). W związku z tak postawioną tezą Lee opowiada się za „socjologią niedojrzałości” (Lee 2001), w której postrzega się dzieciństwo (podobnie jak dorosłość) jako „konstytucjonalnie niekompletne” i „niestabilne” (Lee 1998: 465). Ujmowanie dzieciństwa w taki sposób wskazuje na to, że jest ono zjawiskiem podlegającym ciągłym zmianom, w czym istotną rolę odgrywają przeobrażenia, jakim ulega współczesny świat. Prowadzą one do stopniowego rozmywania się granic pomiędzy dorosłością a dzieciństwem, co sprawia, że dzieciństwo jawi się jako stan, którego zasięg stale się poszerza. Valerie Walkerdine zwraca przy tym uwagę na kulturowe uwarunkowania sygnalizowanego tu zjawiska: „W świecie zachodnim doszło do historycznej zmiany, w wyniku której dzieciństwo i dorosłość, bycie i stawanie się, przestały już być wyrazistymi i rozdzielnymi kategoriami, podczas gdy dla wielu dorosłych i dzieci spoza zachodniego obszaru kulturowego kategorie te nigdy nie były ani wyraziste, ani rozdzielone" (2008: 143).

Ostatnią z wymienionych dychotomii jest opozycja kultura vs natura. Badacze skupieni w nurcie nowej fali poddają ją szczególnie wnikliwej i krytycznej analizie. Jak przekonuje Alan Prout, do zakorzenienia się tej dychotomii w dyskursie nowej socjologii dzieciństwa przyczyniło się powtarzanie jak mantry tezy głoszonej przez społecznych konstruktywistów, zgodnie z którą dzieciństwo powinno być rozumiane jako dyskursywnie konstruowany fenomen historyczny, społeczny i kulturowy (Prout 2005). Przyjęcie poglądu, według którego dzieciństwo stanowi zjawisko przynajmniej częściowo konstruowane dyskursywnie, należy uznać za ważne i inspirujące zarówno w warstwie refleksji teoretycznej, jak i badań empirycznych. Istnieje jednak realne niebezpieczeństwo, że ta perspektywa postrzegania dzieciństwa stanie się odwrotnością perspektywy modernistycznej, czyli dyskursem, w którym kategoria „społeczeństwo” zastąpi kategorię „natura" (Prout 2005: 56).

Opisywanie dziecka i dzieciństwa z perspektywy społecznego konstruktywizmu z definicji łączy się z oddzieleniem tego, co społeczne/kulturowe, od tego, co biologiczne/naturalne w dziecku i w dzieciństwie. Wychodząc poza ramy tej perspektywy, Prout (2005) stawia tezę o złożonym, hybrydycznym charakterze dzieciństwa, co oznacza, że fenomen dzieciństwa łączy w sobie heterogeniczne wytwory kultury i natury. W tym sformułowaniu widać bezpośrednie nawiązanie do Latoura, który w swoich pracach używa określenia „heterogeniczne sieci tego, co społeczne” w celu wykazania, że ludzkie społeczeństwa kreowane są za pośrednictwem złożonych mediacji między kulturą i naturą. Sieci te, podkreśla Latour, są jednocześnie „realne, tak jak natura, narracyjne, tak jak dyskurs i zbiorowe, tak jak społeczeństwo" (Latour 1993: 6). 
Zmierzając do ukazania problematycznego charakteru dychotomii wpisanych w założenia nowej socjologii dzieciństwa, odwoływałam się do zjawisk zachodzących w przestrzeni między biegunami tych dychotomii, w przestrzeni, którą Prout nazywa „wykluczonym środkiem" (excluded middle) (Prout 2011). Analiza tych zjawisk wskazuje na zmiany zachodzące $\mathrm{w}$ zakresie, treści i jakości dziecięcych doświadczeń, zmiany sprawiające, że coraz bardziej wyrazista staje się wielość i różnorodność sposobów doświadczania i przeżywania świata przez dzieci usytuowane zarówno w odmiennych, jak i tych samych kulturach, klasach społecznych czy grupach etnicznych. Przeobrażenia, którym podlega współczesny świat, zmieniają życie dzieci i dorosłych, prowadzą do rozmywania się granic między kategoriami, które dotychczas uznawano za stałe i niezmienne. Dzieciństwo jawi się w tym kontekście jako złożony, niejednoznaczny i zdestabilizowany fenomen (Prout 2005).

\section{Wychodzenie poza dychotomie w kategoryzacji dzieciństwa}

Prowadzone dotychczas rozważania uzasadniają postawienie tezy, zgodnie z którą wpisane w założenia nowej socjologii dzieciństwa dychotomicznie ujmowane kategorie nie są w stanie oddać złożoności fenomenu dzieciństwa. Zwolennicy nowej fali badań zaproponowali w związku z tym użycie kategorii, które pozwalają na odejście od języka binarnych opozycji w procesie opisywania i analizowania dzieciństwa. Alan Prout, jako jeden z pierwszych, zaproponował zastosowanie nielinearnego języka, a w nim takich kategorii pojęciowych, jak sieć, mobilność i relacyjność (Prout 2005, 2011). Zasadniczym źródłem teoretycznym, z którego autor czerpał inspirację, budując własną koncepcję narzędzi analitycznych, była teoria aktora-sieci (ANT - Actor-Network Theory) (Latour 2010).

Teoria aktora-sieci odrzuca myślenie esencjalistyczne, co oznacza, że wszelkie obiekty postrzega się w niej i analizuje przez pryzmat dynamicznych relacji, w jakie wchodzą one $\mathrm{z}$ innymi obiektami. Relacje te zachodzą w płynnej i heterogenicznej sieci między usytuowanymi w niej aktorami (bytami działającymi), należącymi zarówno do „rzeczywistości ludzkiej", jak i pozaludzkiej (aktorami mogą być urządzenia techniczne, firmy, mikroby i in.) (Arbiszewski 2010). Wszyscy aktorzy traktowani są jako hybrydy kultury i natury, które konstytuują się za pośrednictwem sieci połączeń i rozłączeń. Aktora definiuje się zatem nie przez odwoływanie się do zbioru esencjonalnych cech, lecz przez odniesienie się do tego, jak może on wpływać na innych. W ANT nie ma więc mowy o „strukturach i umieszczaniu aktorów w z góry wyznaczonych dla nich przegródkach" (Arbiszewski 2010: XIII). Przeciwnie, aktorzy tworzą relacyjne całości (sieci), których kształt „wyłania się właśnie w trakcie tych procesów tworzenia" (Arbiszewski 2010: XIII). W ramach ANT postuluje się zatem koncentrację na procesach, a nie na bytach.

Nawiązując do przywołanej teorii, Prout posłużył się metaforą sieci do wykazania, że dzieciństwo można postrzegać jako kolekcję konkurujących ze sobą, a czasami pozostających ze sobą w konflikcie porządków. Dzieci są usytuowane i działają w sieciach różnorodnych połączeń, z każdym bowiem aktorem związana jest złożona, mniej lub bardziej 
trwała sieć ludzi i rzeczy. Nowe formy dzieciństwa pojawiają się wtedy, gdy wytwarzają się nowe zestawy połączeń sieciowych, np. między dziećmi i technologiami takimi jak telewizja czy Internet (Prout 2011).

Kategoria sieci jest ściśle powiązana w koncepcji Prouta z dwiema pozostałymi z mobilnością i relacyjnością. Kategoria mobilności wiąże się z przepływem i zmiennością procesów i zjawisk zachodzących w sieciach relacji, w których usytuowane są dzieci. Autor odnosi tę kategorię m.in. do wzrastającej częstotliwości przemieszczania się ludzi, która w wymiarze globalnym prowadzi do powstawania takich zjawisk, jak dostrzeżone przez Barrie Thorne zjawisko „ponadnarodowych dzieciństw” (Thorne, za: Prout 2011: 10). Mobilność ujawnia się także w wymiarze lokalnym, w codziennym życiu dzieci, w znaczeniach, jakie nadają one na przykład czasowi spędzonemu w domu rodzinnym. Jak pokazują w badaniach Pii Christensen i wsp. (2000), dzieci postrzegają swój pobyt w domu przez pryzmat kategorii „przychodzenie i wychodzenie”, oznaczającej częste przemieszczanie się członków rodziny.

Kategorię mobilności autor łączy także z przepływami zachodzącymi w różnych miejscach (i pomiędzy nimi) w obrębie przestrzeni zajmowanej przez dzieci. W przestrzeni tej znajdują się m.in. szkoły, które są powiązane z innymi instytucjami edukacyjnymi, gospodarstwami domowymi, placami zabaw, lokalnymi władzami, ministerstwami itd. Ludzie przekraczają granice między tymi miejscami, niosąc ze sobą różne doświadczenia, idee, wartości oraz różne zasoby materialne. Granice te przekraczają również rzeczy, którymi są teksty (np. programy, przewodniki i materiały do nauczania) oraz maszyny (np. komputery) dające określone możliwości uczenia się. „Ludzie i rzeczy, które przepływają przez te miejsca (i pomiędzy nimi), są hybrydycznymi aktantami, które odgrywają istotną rolę w konstruowaniu tego, co wyłania się jako dzieciństwo w tych miejscach" (Prout 2011: 11).

Trzecią kategorią pojęciową zastosowaną przez Prouta jest relacyjność. Autor odnosi ją głównie do związków międzygeneracyjnych dzieci - dorośli. Użycie kategorii relacyjności w odniesieniu do tych związków umożliwia odejście od postrzegania ich jako niezmiennej, ustanowionej raz na zawsze struktury. Pozwala na rozpatrywanie związków między dziećmi i dorosłymi w ujęciu procesualnym, które zakłada możliwość tworzenia się różnych „porządków generacyjnych” (generational orderings) (Prout 2011: 12).

$\mathrm{W}$ czasach nam najbliższych w kwestii wychodzenia poza dychotomie w badaniach nad dzieciństwem wypowiada się Spyros Spyrou, optujący za używaniem kategorii relacyjności (Spyrou 2019). Autor prowadzi swoje rozważania w kontekście dokonującego się w obszarze nauk społecznych tzw. zwrotu ontologicznego. Zwrot ten stanowi reakcję na zwrot lingwistyczny z lat 90 . XX wieku. Ten ostatni koncentrował się na języku, dyskursie i reprezentacji, ten pierwszy kieruje się natomiast w stronę ,materialności życia” (Spyrou 2019: 316). Jego zwolennicy krytycznie odnoszą się do społecznego konstruktywizmu i jednocześnie przekonują o konieczności uznania znaczącej roli materii w tworzeniu ludzkich światów życia. W wielu pracach omawiających zwrot ontologiczny przyjmuje się orientację posthumanistyczną (por. np. Braidotti 2014), w obrębie której kwestionuje 
się centralną pozycję człowieka w świecie. W centrum analizy sytuuje się duże sieci sił materialnych i dyskursywnych, które konstytuują świat. Umieszczając istoty ludzkie poza centrum świata, posthumanizm podważa przypisywaną człowiekowi uprzywilejowaną pozycję i wprowadza pojęcie relacyjności, które sygnalizuje, że różne byty konstytuują się w relacjach, jakie zachodzą między ludźmi i bytami nie ludzkimi.

Przyjęcie perspektywy nowego materializmu w badaniach nad dzieciństwem wiąże się z usytuowaniem dzieci w sieci złożonych relacji, w jakie wchodzą z innymi ludźmi i z jednostkami/bytami pozaludzkimi. Pociąga to za sobą przyjęcie tezy wychodzącej poza ujęcia esencjalistyczne, zgodnie z którą podmiotowość dzieci jest czymś, co wyłania się $\mathrm{z}$ tych skomplikowanych relacji. Podobne założenia czyni się w odniesieniu do dzieciństwa, uznając je za zjawisko niestabilne, podlegające ciągłym zmianom, wyłaniające się z sieci różnych konstytuujących je czynników. Akceptacja tego punktu wiąże się z wysunięciem na plan pierwszy, w warstwie założeń ontologicznych badań nad dzieciństwem, pytania o to, w jaki sposób konstytuowane jest dzieciństwo (Spyrou 2019).

\section{Zakończenie}

Rozważania podjęte $\mathrm{w}$ artykule zmierzały do ukazania sposobu rozumienia dziecka i dzieciństwa $\mathrm{w}$ jednym $\mathrm{z}$ nurtów socjologii dzieciństwa, zwanym nową falą. $\mathrm{Z}$ przeprowadzonej analizy sposobów opisywania dzieci i dzieciństwa przez twórców i zwolenników tego nurtu badawczego wyłania się obraz dzieciństwa jako fenomenu, w którym kultura spotyka się z naturą, w którym to, co społeczne, splata się nierozerwalnie z tym, co naturalne. Nakreśla ona również obraz dziecka jako wielowymiarowej, biopsychospołecznej istoty, której życie rozgrywa się w sieciach splątanych ze sobą elementów biologicznych, społecznych i kulturowych, ludzkich i nie ludzkich. Ukazany holistyczny sposób rozumienia dziecka i dzieciństwa ma swoje implikacje edukacyjne, które łączą się, zgodnie z sugestiami Affrici Taylor i wsp., z potrzebą „,wychodzenia poza horyzont podejść edukacyjnych, w których dziecko postrzegane jest jako osoba rozwijająca się i ucząca wyłącznie w ludzkim kontekście społeczno-kulturowym" (Taylor i in. 2013: 48). Oznacza to wchodzenie w krajobraz posthumanistyczny, w którym dziecko będzie miało możliwość uczenia się świata w bezpośrednim z nim kontakcie, nawiązując wielokierunkowe relacje z bytami ludzkimi i pozaludzkimi (Lenz Taguchi 2011; Taylor i in. 2013; Taylor, Pacini-Ketchabaw 2015).

Nowy sposób myślenia o dziecku i dzieciństwie, o kontekście życia, rozwoju i uczenia się dziecka skłania też do refleksji nad możliwymi przesunięciami w ontologicznych założeniach badań nad dzieciństwem. Zwrócenie uwagi na potrzebę dokonania przekształceń w ontologii dzieciństwa nie musi, jak przekonuje Spyrou, oznaczać konieczności ,przeorientowania całego pola badawczego, lecz jedynie doprowadzić do ożywienia refleksji teoretycznej w jego obszarze" (2019: 321). 


\section{Literatura}

Alderson P., Goodwin M. (1993), Contradiction within Concepts of Children's Competence. „International Journal of Children's Rights", 1.

Arbiszewski K. (2010), Splatajac na nowo ANT. Wstęp. W: B. Latour, Splatajac na nowo to, co społeczne. Wprowadzenie do teorii aktora-sieci. Kraków, Universitas.

Bauman Z. (1995), Wieloznaczność nowoczesna. Nowoczesność wieloznaczna. Warszawa, Wydawnictwo Naukowe PWN.

Braidotti R. (2014), Po człowieku. Warszawa, Wydawnictwo Naukowe PWN.

Christensen P., James A., Jenks C. (2000), Home and Movement: children constructing family time.

W: S. Holloway, G. Valentine (eds.), Children's Geographies: living, playing and transforming everyday worlds. London, Routledge.

James A., Jenks C., Prout A. (1998), Theorising Childhood. Cambridge, Polity Press.

Jenks C. (2008), Socjologiczne konstrukty dzieciństwa. W: M.J. Kehily (red.), Wprowadzenie do badań nad dzieciństwem. Kraków, Wydawnictwo WAM.

Kousky C. (2016), Impacts of Natural Disasters on Children. „The Future of Children”, 26(1).

Kowalik-Olubińska M. (2020), Dzieci w obliczu zmiany klimatu - obraz dziecięcej partycypacji w raportach międzynarodowych organizacji pozarzadowych. „Forum Pedagogiczne”, 1.

Latour B. (1993), We Have Never Been Modern. Cambridge, Harvard University Press.

Latour B. (2010), Splatając na nowo to, co społeczne. Wprowadzenie do teorii aktora-sieci. Kraków, Universitas.

Lee N. (1998), Towards an Immature Sociology. „The Sociological Review”, 46.

Lee N. (2001), Childhood and society: growing up in an age of uncertainty. Buckingham, Open University Press.

Lenz Taguchi H. (2011), Investigating Learning, Participation and Becoming in Early Childhood Practices with a Relational Materialist Approach. „Global Studies of Childhood”, 1(1).

Mayall B. (2002), Towards a Sociology for Childhood. Buckingham, Open University Press.

Mizen P., Ofosu-Kusi Y. (2010), Asking, giving, receiving: friendship as survival strategy among Accra's street children. „Childhood”, 17.

Prout A. (2005), The Future of Childhood: towards the interdisciplinary study of children. London, Routledge Falmer.

Prout A. (2011), Taking a Step Away from Modernity: reconsidering the new sociology of childhood. „Global Studies of Childhood”, 1(1).

Prout A., James A. (1990), A New Paradigm for Sociology of Childhood? Provenance, Promise and Problems. W: A. James, A. Prout (eds.), Constructing and Reconstructing Childhood. Contemporary Issues in the Sociological Study of Childhood. London, Falmer Press.

Qvortrup J., Corsaro W.A., Honig M.-S. (2009), Why Social Studies of Childhood? An Introduction to the Handbook. W: J. Qvortrup, W.A. Corsaro, M.-S. Honig (eds.), The Palgrave Handbook of Childhood Studies. Houndmills, Palgrave Macmillan.

Rorty R. (2009), Przygodność, ironia i solidarność. Warszawa, Wydawnictwo W.A.B.

Ryan K. (2012), The new wave of childhood studies: breaking the grip of biosocial dualism? „Childhood", 19.

Spyrou S. (2019), An Ontological Turn for Childhood Studies? „Children \& Society”, 33. 
Taylor A., Blaise M., Giungi M. (2013), Haraway's 'bag lady story-telling': relocating childhood and learning within a 'posthumanist landscape'. „Discourse: Studies in the Cultural Politics of Education", 34(1).

Taylor A., Pacini-Ketchabaw V. (2015), Learning with Children, Ants, and Worms in the Anthropocene: Towards a Common World Pedagogy of Multispecies Vulnerability. „Pedagogy, Culture \& Society", 24(3).

Tisdall E.K.M., Punch S. (2012), Not So 'New'? Looking Critically at Childhood Studies. „Children's Geographies", 10(3).

Vandenbroeck M., Bouverne-De Bie M. (2006), Children's Agency and Educational Norms: A tensed negotiation. „Childhood”, 13.

Walkerdine V. (2008), Psychologia rozwojowa i badania dzieciństwa. W: M.J. Kehily (red.), Wprowadzenie do badań nad dzieciństwem. Kraków, Wydawnictwo WAM. 